\title{
PEMANFAATAN AIR DAERAH ALIRAN SUNGAI (DAS) WAE BOBO UNTUK MEMENUHI KEBUTUHAN AIR IRIGASI GUNA MENINGKATKAN HASIL PERTANIAN DI KABUPATEN MANGGARAI TIMUR PROVINSI NUSA TENGGARA TIMUR
}

\author{
Joko Suparmanto(1), Sutirto ${ }^{(2)}$ \\ Dosen Teknik Sipil Politeknik Negeri Kupang \\ Email.: suparmanto590@gmail.com, sutirtojatayu@g.mail.com
}

\begin{abstract}
Abstrak
Pertanian sangat erat kaitannya dengan tersedianya air dimana air sangat diperlukan untuk mengairi areal pertanian dalam usaha peningkatan produksi pertanian. Namun masalah yang sering timbul adalah tidak tersedianya air yang cukup untuk mengairi areal pertanian. DAS merupakan sebuah ruang yang didalamnya mencakup SDA dan SDM. DAS Wae Bobo terletak di Kabupaten Manggarai Timur memiliki 7 Daerah Irigasi dengan total luas areal $777 \mathrm{Ha}$, mempunyai ketersediaan air dari aliran sungai Wae Bobo pada Bulan Januari sebesar 1,584 $\mathrm{m}^{3} / \mathrm{detik}$ dan yang terkecil pada Bulan Oktober sebesar 0,4163/detik. Debit andalan ( $Q_{80}$ ) yang terbesar terjadi pada bulan januari sebesar $1,235 \mathrm{~m}^{3} /$ detik dan yang terkecil pada bulan Oktober sebesar $0,109 \mathrm{~m}^{3} /$ detik. Kebutuhan air untuk irigasi yang terbesar pada bulan Januari sebesar $0,576 \mathrm{~m}^{3} /$ detik dan yang terkecil Oktober $\mathrm{r} 0,055 \mathrm{~m}^{3} /$ detik. Untuk menghasilkan debit yang balance surplus guna kebutuhan irigasi dibuat sistem pola tanam padi-padi-polowijo dengan musim tanam diawali pada Bulan November untuk meningkatkan hasil pertnaian.
\end{abstract}

Kata Kunci : Ketersedian air di DAS, pola tanam, meningkatkan hasil pertanian

\begin{abstract}
PENDAHULUAN
\section{Latar belakang}

Indonesia sebagai Negara Pertanian memiliki kekayaan alam yang sangat berlimpah baik bumbu maupun mineral yang terkandung di dalamnya. Seperti kita ketahui, pertanian erat kaitannya dengan ketersediaan air, di mana air dibutuhkan untuk mengairi areal pertanian dalam upaya meningkatkan produksi pertanian yang umumnya menggunakan irigasi. Namun masalah yang sering muncul adalah tidak tersedianya cukup air untuk mengairi areal pertanian.
\end{abstract}

Organisasi lingkungan dunia Green Peace mengatakan bahwa $72 \%$ dari hutan Indonesia dihancurkan dan setengah dari area hutan yang masih dalam bahaya terancam oleh penebangan komersial, kebakaran hutan, dan pembukaan hutan untuk kegiatan pertanian. Laju degradasi hutan setiap tahun mencapai 2,83 juta hektar. Dari total 120,5 juta hektar kawasan hutan, sekitar 59 juta hektar berada dalam kondisi kritis. (Jawa Pos, Selasa 4 September 2007 : hal 14).

Provinsi Nusa Tenggara Timur adalah provinsi di Indonesia yang berada di kluster Sunda Kecil dan termasuk dalam Kepulauan Nusa Tenggara, memiliki 22 Kabupaten / Kota. terdiri dari sekitar 550 pulau, 4 pulau besar / utama, yaitu: Pulau Flores, Pulau Sumba, Pulau Timor dan Pulau Alor.
Daerah Aliran Sungai (DAS) Wae Bobo terletak di Kabupaten Manggarai Timur memiliki 7 (tujuh) Daerah Irigasi dengan total luas areal $777 \mathrm{Ha}$, meliputi Daerah Irigasi Wae Bobo seluas $150 \mathrm{Ha}$, Daerah Irigasi Wae Bobo II seluas $80 \mathrm{Ha}$, Daerah Irigasi Wae Bobo III Lolang $50 \mathrm{Ha}$, Daerah Irigasi Wae Bobo Mura I seluas $117 \mathrm{Ha}$, Daerah Irigasi Wae Bobo Mura II seluas $85 \mathrm{Ha}$, Daerah Irigasi Wae Bobo Racang I seluas $195 \mathrm{Ha}$, dan Daerah Irigasi Wae Bobo Racang II seluas $100 \mathrm{Ha}$. Fasilitas pengambilan di daerah irigasi sekarang mengalami penurunan kualitas sehingga kapasitas aktual telah jatuh sangat jauh dari kapasitas desain yang telah mengakibatkan berkurangnya area pertanian yang dapat dirigasi. Sehubungan dengan hal tersebut, mengingat kondisi topografi dan ketersedian air, alternatif dibangunnya suatu Bendung untuk mengangkat elevasi muka air dan jaringan saluran sangat diperlukan. Sebagai langkah awal dalam mengoptimalkan daerah aliran sungai adalah dengan melakukan desain potensi sumber daya yang ada dengan menganalisa potensi ketersedian air, kebutuhan air dan keseimbangan air, sehingga pengelolaan air dapat terlaksana dengan baik dimasa sekarang maupun dimasa yang akan datang.

Sesuai permasalahan diatas perlu suatu kajian untuk diteliti tentang pemanfaatan air sungai Wae Bobo guna memenuhi kebutuhan air irigasi di Kabupaten Manggarai Timur Provinsi Nusa Tenggara Timur 


\section{Perumusan Masalah}

Berdasarkan permasalahan diatas diperoleh rumusan masalah sebagai berikut :

1. Berapa besar debit ketersediaan air pada Daerah Aliran Sungai (DAS) Wae Bobo?

2. Berapa besar kebutuhan air untuk irigasi pada Daerah Aliran Sungai (DAS) Wae Bobo?

3. Berapa neraca air sesuai ketersediaan dan kebutuhan air di Daerah Aliran (DAS) Sungai Wae Bobo?

\section{METODE PENELITIAN}

Lokasi penelitian di Daerah Aliran Sungai Wae Bobo Kabupaten Manggarai Timur Provinsi Nusa Tenggara Timur. Berdasarkan koordinat geografi, hulu DAS Wae Bobo terletak : 08 38' 9,27" LS, 120'39' 10,51" BT dan hilir/muara DAS Wae Bobo terletak : $08^{\circ} 49^{\prime} 11,58^{\prime \prime}$ LS, $120^{\circ} 36^{\prime}$ 20,87" BT dengan kemiringan lahan antara 5 - $8 \%$, berada pada ketinggian antara $+30 \mathrm{~m}$ sampai dengan $+300 \mathrm{~m}$, di atas permukaan laut. Batas-batas daerah pengaliran DAS Wae Bobo, yaitu:

a. Sebelah Utara, berbatasan dengan Wilayah Hutan Lidung TWA Ruteng.

b. Sebelah Selatan, berbatasan langsung dengan Laut Sawu pantai selatan (Pantai Cepi Watu).

c. Sebelah Timur, berbatasan dengan Jl. Kisol-Paan Leleng - Jong- Waling.

d. Sebelah Barat, berbatasan dengan Jl. BorongMbeling-Bangga Rangga.

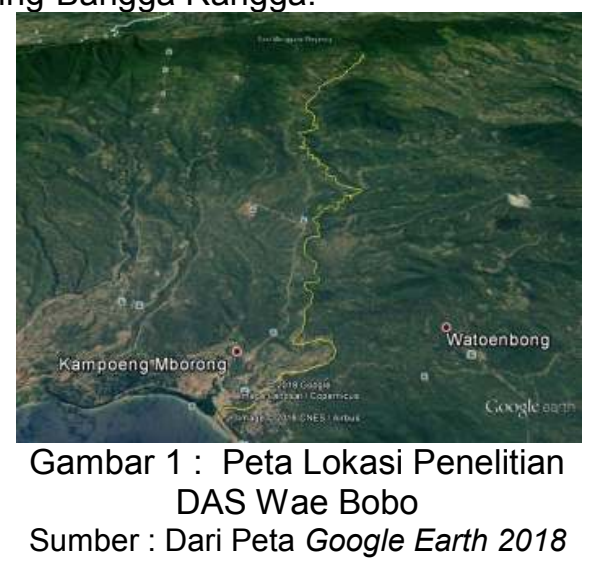

\section{Langkah - langkah Penelitian}

Langkah awal dalam penelitian ini mengumpulkan referensi-referensi digunakan sebagai dasar dalam penelitian yang berhubungan dengan sumber daya air, selanjutnya dilakukan analisis hidrologi. Salah satu parameter hidrologi yang penting dalam suatu pekerjaan terkait sumber daya air adalah menghitung debit air yang tersedia, menghitung kebutuhan air yang dibutuhkan di sawah dengan cara alternatif pola tanam dan menghitung keseimbangan air irigasi. adalah :
1. Data Peta Topografi

a.Peta lokasi DAS (Daerah Aliran Sungai) Wae Bobo Skema jaringan irigasi ( Dinas Pekerjaan Umum Kabupaten Manggarai Timur).

2.Data Hidrologi, 15 Tahun terakhir (BMKG Stasiun Klimatologi Lasiana Kupang)

a.Data curah hujan stasiun meteorologi Mborong.

b.Data curah hujan stasiun meteorologi Wae Pana

3.Data Klimatologi, 15 Tahun terakhir (BMKG Stasiun Klimatologi Lasiana Kupang) pos klimatologi stasiun Ruteng.

a. Suhu

b. Radiasi Matahari

c. Kelembaban

d. Kecepatan Angin

4. Analisis Ketersediaan Air

a.Menghitung jumlah rata-rata curah hujan $1 / 2$ bulanan

b.Menghitung evapotranspirasi potensial

c. Perhitungan keseimbangan air pada permukaan tanah, limpasan (run off) dan tampungan air tanah (ground water storage) aliran sungai.

d.Perhitungan debit andalan

5. Analisis Kebutuhan Air Irigasi

Analisis kebutuhan air irigasi didasari oleh perencanaan tata tanam dengan metode water balance meliputi:

1.Kebutuhan air untuk tanaman (ETc)

2. Kebutuhan air akibat perkolasi dan rembesan $(P)$

3. Kebutuhan air untuk pergantian lapisan air (WLR)

4. Kebutuhan air untuk penyiapan lahan $(P L)$

5. Curah hujan efektif (Ref

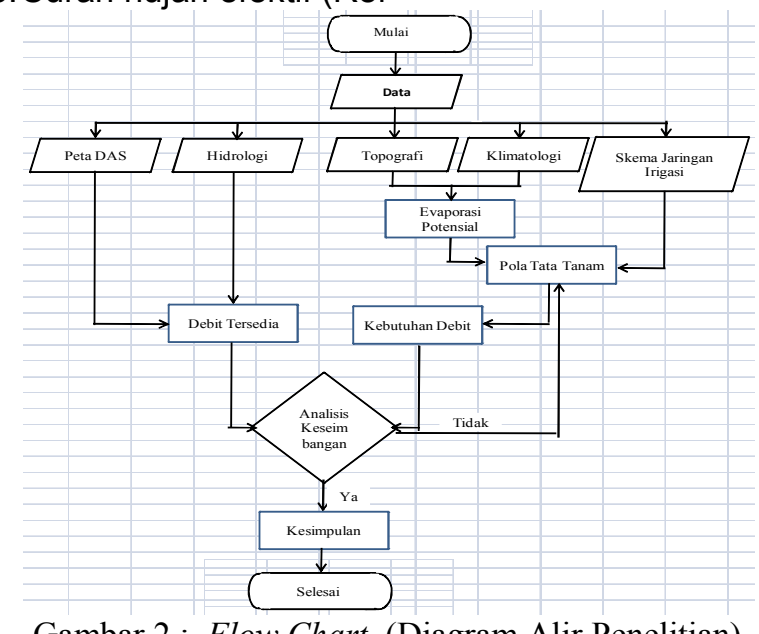

Gambar 2: Flow Chart (Diagram Alir Penelitian)

\section{HASIL DAN PEMBAHASAN}

\section{Penentuan Daerah Aliran Sungai (DAS)}

Keadaan morfologi sungai Wae Bobo daerah pegunungan / pegunungan. Daerah pengaliran sungai Wae Bobomemiliki panjang $\pm 21,05 \mathrm{~km}$ dengan luas $\pm 130,41 \mathrm{Km}^{2}$. 


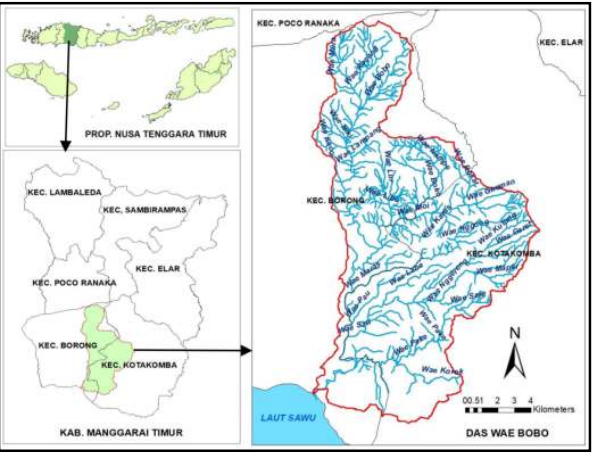

Gambar 3 : DAS Oebobo

\section{Analisis Curah Hujan}

\section{Ketersediaan Data Hujan}

Untuk mendapatkan hasil yang memiliki akurasi tinggi, dibutuhkanketersediaan data yang secara kualitas dan kuantitas cukup memadai. Data hujan yang digunakan direncanakan selama 15 tahun sejak Tahun 2003 hingga Tahun 2017.

\section{Analisis Curah Hujan Area}

Perhitungan Curah Hujan Rata-rata Daerah DAS Wae Bobo dilakukan dengan pendekatan Metode Rata-rata Aljabar. Curah hujan rata-rata di suatu DAS diperoleh dengan cara rata-rata aritmatika dari alat pengukur curah hujan daerah dibagi dengan jumlah stasiun pengamatan (Sosrodarsono dan Takeda, 1976). Hasil perhitungan curah hujan rata-rata DAS WaeBobo disajikan pada Tabel berikut :

Tabel 23: C Hujan Rata-Rata Daerah DAS WaeBobo

\begin{tabular}{|c|c|c|c|c|}
\hline \multirow{2}{*}{ No. } & \multirow{2}{*}{ Tahun } & \multicolumn{2}{|c|}{ Data Curah Hujan (mm) } & \begin{tabular}{c} 
Curah Hujan \\
\cline { 3 - 4 }
\end{tabular} \\
\cline { 3 - 4 } & Stasiun Mborong & Stasiun Wae Pana & Rata-rata Daerah \\
\hline 2 & 2003 & 201 & 60 & 130,5 \\
\hline 3 & 2005 & 152 & 64 & 108 \\
\hline 4 & 2006 & 95 & 125 & 110 \\
\hline 5 & 2007 & 212 & 55 & 121 \\
\hline 6 & 2008 & 93 & 94 & 153 \\
\hline 7 & 2009 & 77 & 78 & 85,5 \\
\hline 8 & 2010 & 81 & 82 & 79,5 \\
\hline 9 & 2011 & 50 & 90 & 85,5 \\
\hline 10 & 2012 & 228 & 370 & 210 \\
\hline 11 & 2013 & 61 & 210 & 219 \\
\hline 12 & 2014 & 45 & 64 & 62,5 \\
\hline 13 & 2015 & 31,5 & 90 & 67,5 \\
\hline 14 & 2016 & 31,5 & 215 & 123,25 \\
\hline 15 & 2017 & 25 & 74 & 52,75 \\
\hline
\end{tabular}

.Sumber : Hasil Perhitungan, 2018

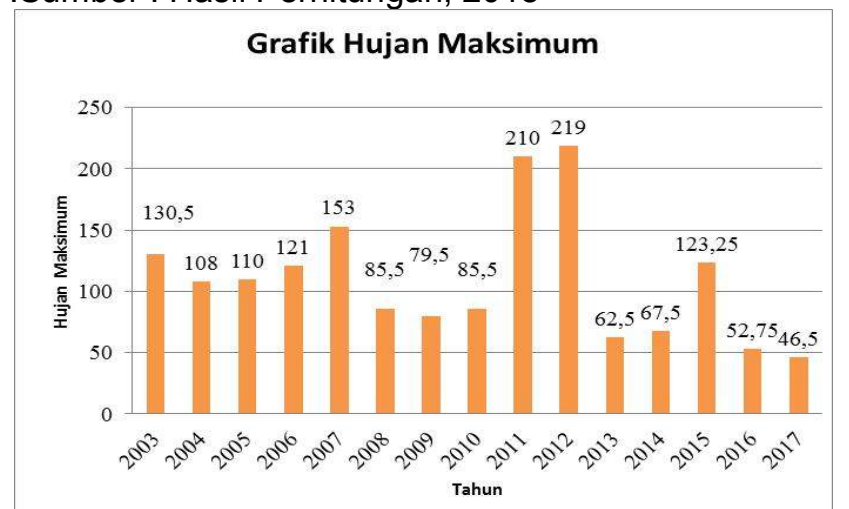

Gambar 4 Grafik Curah Hujan Rata-rata Daerah DAS Wae Bobo

Sumber : Hasil Analisis, 2018

\section{Analisis Kebutuhan Air}

\section{Kebutuhan Air Untuk Tanaman}

Jumlah evapotranspirasi

dihitung menggunakan Metode Penman yang dimodifikasi oleh Nedeco / Prosida seperti yang dijelaskan dalam PSA -010. Evapotranspirasi dihitung dengan mengguna kan rumus-rumus teoritis empiris dengan memperhatikan faktor-faktor meteorologi yang terkait seperti suhu udara, kelembaban, kecepatan angin dan penyinaran matahari. Selanjutnya untuk menda patkan harga evapotaranspirasi harus dikalikan dengan koefisien tanaman tertentu. Sehingga evapotranspirasi sama dengan evapotranspirasi potensial dari perhitungan Penman $x$ crop factor. Dari harga evapotranspirasi yang diperoleh, kemudian digunakan untuk menghitung kebutuhan air untuk pertumbuhan dengan memasukkan data curah hujan yang efektif. Hasil perhitungan untuk mencari di tabelkan sebagai berikut :

Tabel 1 : Perhitungan Mencari Besaran ea Berdasarkan Temperatur

\begin{tabular}{|l|c|c|c|c|c|c|c|c|c|c|c|c|}
\hline Bulan & Jan & Feb & Mar & Apr & Mei & Jun & Jul & Ags & Sep & 0kt & Nov & Des \\
\hline
\end{tabular} \begin{tabular}{|l|l|l|l|l|l|l|l|l|l|l|l|l|}
\hline Temp. $\left({ }^{\circ} \mathrm{C}\right)$ & 23,22 & 22,82 & 22,82 & 22,92 & 22,52 & 21,62 & 21,22 & 21,32 & 22,72 & 23,92 & 24,02 & 23,72 \\
\hline
\end{tabular}

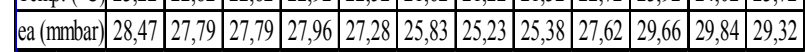

Sumber : Hasil Analisis, 2018

Tabel 2 : .Perhitungan mencari besaran (1-w)

\begin{tabular}{|l|c|c|c|c|c|c|c|c|c|c|c|c|}
\hline Bulan & Jan & Feb & Mar & Apr & Mai & Jun & Jul & Asg & Sep & 0kt & Nov & Des \\
\hline
\end{tabular}

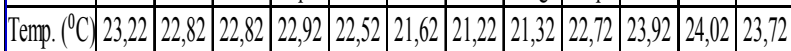
\begin{tabular}{l|l|l|l|l|l|l|l|l|l|l|l|l|l|l|l}
\hline$(1-W)$ & 0,278 & 0,282 & 0,282 & 0,281 & 0,285 & 0,294 & 0,298 & 0,297 & 0,283 & 0,271 & 0,270 & 0,273 \\
\hline
\end{tabular}

Sumber : Hasil Analisis, 2018

Tabel 3 : .Perhitungan mencari besaran (W)

\begin{tabular}{|l|c|c|c|c|c|c|c|c|c|c|c|c|}
\hline Bulan & Jan & Feb & Mar & Apr & May & Jun & Jul & Agt & Sep & Okt & Nov & Des \\
\hline
\end{tabular} \begin{tabular}{|l|l|l|l|l|l|l|l|l|l|l|l|l|l|}
\hline Temp. $\left({ }^{\circ} \mathrm{C}\right)$ & 23,22 & 22,82 & 22,82 & 22,92 & 22,52 & 21,62 & 21,22 & 21,32 & 22,72 & 23,92 & 24,02 & 23,72 \\
\hline
\end{tabular} \begin{tabular}{|l|l|l|l|l|l|l|l|l|l|l|l|l|}
\hline $\mathrm{W}$ & 0,723 & 0,719 & 0,719 & 0,720 & 0,716 & 0,705 & 0,700 & 0,701 & 0,718 & 0,730 & 0,731 & 0,728 \\
\hline
\end{tabular}

Sumber : Hasil Analisis, 2018

Tabel 4 : .Perhitungan mencari besaran (Ra) \begin{tabular}{|l|c|c|c|c|c|c|c|c|c|c|c|c|}
\hline Bulan & Jan & Feb & Mar & Apr & Mei & Jun & Jul & Agt & Sep & Okt & Nov & Des \\
\hline
\end{tabular} \begin{tabular}{|l|l|l|l|l|l|l|l|l|l|l|l|l|}
\hline L. S $\left({ }^{0} \mathrm{C}\right)$ & 8,45 & 8,45 & 8,45 & 8,45 & 8,45 & 8,45 & 8,45 & 8,45 & 8,45 & 8,45 & 8,45 & 8,45 \\
\hline
\end{tabular} \begin{tabular}{|l|l|l|l|l|l|l|l|l|l|l|l|l|l|}
\hline $\operatorname{Ra}(\mathrm{mm} / \mathrm{jam})$ & 16,17 & 16,15 & 15,50 & 14,36 & 13,03 & 12,31 & 12,63 & 13,66 & 14,88 & 15,82 & 16,05 & 16,05 \\
\hline
\end{tabular}

Sumber : Hasil Analisis, 2018

Tabel 5 : .Perhitungan mencari besaran (N)

\begin{tabular}{|l|c|c|c|c|c|c|c|c|c|c|c|c|}
\hline Bulan & Jan & Feb & Mar & Apr & Mei & Jun & Jul & Agt & Sep & 0kt & Nov & Des \\
\hline L. $S\left({ }^{\circ} \mathrm{C}\right)$ & 8,45 & 8,45 & 8,45 & 8,45 & 8,45 & 8,45 & 8,45 & 8,45 & 8,45 & 8,45 & 8,45 & 8,45 \\
\hline $\mathrm{N}$ & 0,13 & 0,12 & 0,12 & 0,12 & 0,12 & 0,12 & 0,12 & 0,12 & 0,12 & 0,12 & 0,13 & 0,13 \\
\hline
\end{tabular}

Sumber : Hasil Analisis, 2018

Tabel 6 : .Perhitungan mencari besaran $\mathrm{f}(\mathrm{T})$

\begin{tabular}{|l|c|c|c|c|c|c|c|c|c|c|c|c|}
\hline Bulan & Jan & Feb & Mar & Apr & Mei & Jun & Jul & Agt & Sep & 0kt & Nov & Des \\
\hline
\end{tabular} \begin{tabular}{|l|l|l|l|l|l|l|l|l|l|l|l|l|l|}
\hline Temp. $\left.{ }^{\circ} \mathrm{C}\right)$ & 23,22 & 22,82 & 22,82 & 22,92 & 22,52 & 21,62 & 21,22 & 21,32 & 22,72 & 23,92 & 24,02 & 23,72 \\
\hline
\end{tabular}

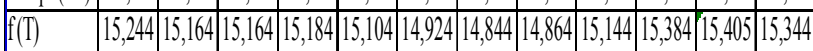

Sumber : Hasil Analisis, 2018

Tabel 7 .Perhitungan mencari besaran $\mathrm{f}(\mathrm{ed})$ \begin{tabular}{|l|c|c|c|c|c|c|c|c|c|c|c|c|}
\hline Bulan & Jan & Feb & Mar & Apr & Mei & Jun & Jul & Agt & Sep & 0kt & Nov & Des \\
\hline
\end{tabular} \begin{tabular}{|l|l|l|l|l|l|l|l|l|l|l|l|l|}
\hline ed (mmbar) & 24,94 & 25,04 & 24,90 & 24,36 & 22,97 & 21,13 & 20,03 & 19,90 & 21,49 & 23,29 & 25,00 & 25,57 \\
\hline
\end{tabular} \begin{tabular}{|l|l|l|l|l|l|l|l|l|l|l|l|l|l|l}
\hline $\mathrm{f}(\mathrm{ed})$ & 0,120 & 0,120 & 0,120 & 0,120 & 0,125 & 0,134 & 0,140 & 0,141 & 0,133 & 0,124 & 0,120 & 0,120 \\
\hline
\end{tabular}

Sumber : Hasil Analisis, 2018

Tabel 8 : Perhitungan mencari besaran $\mathrm{f}(\mathrm{n} / \mathrm{N})$ 
Pemanfaatan Air Daerah Aliran Sungai (Das) Wae Bobo Untuk Memenuhi Kebutuhan Air Irigasi

Guna Meningkatkan Hasil Pertanian Di Kabupaten Manggarai Timur Provinsi Nusa Tenggara

Timur

Joko Suparmanto ${ }^{1 *}$, Sutirto²

\begin{tabular}{|l|l|l|l|l|l|l|l|l|l|l|l|l|}
\hline Bulan & Jan & Feb & Mar & Apr & Mei & Jun & Jul & Agt & Sep & Okt & Nov & Des \\
\hline
\end{tabular}

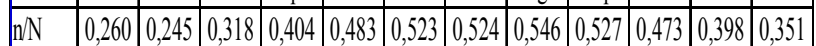
\begin{tabular}{|l|l|l|l|l|l|l|l|l|l|l|l|l|}
$\mathrm{f}(\mathrm{nN})$ & 0,338 & 0,325 & 0,388 & 0,464 & 0,536 & 0,573 & 0,574 & 0,596 & 0,577 & 0,528 & 0,458 & 0,421 \\
\hline
\end{tabular} Sumber : Hasil Analisis, 2018

Tabel 9: Perhitungan mencari Besaran c untuk Rs

\begin{tabular}{|cccc|}
\hline Jan & \multicolumn{3}{c|}{ RH Max $=90 \%$} \\
Rs (mm/hr) & 6 & 6,309 & 9 \\
\cline { 2 - 4 } Ud (m/dt) & Uday / Unight $=2,00$ \\
\cline { 2 - 4 } o & 1,06 & $\mathbf{1 , 0 6 4}$ & 1,10 \\
2,389 & & 1,007 & \\
3 & 0,98 & $\mathbf{0 , 9 9 2}$ & 1,10 \\
\hline
\end{tabular}

Sumber : Hasil Analisis, 2018

Tabel 10 : Perhitungan mencari besaran c

\begin{tabular}{|l|c|c|c|c|c|c|c|c|c|c|c|c|}
\hline Bulan & Jan & Feb & Mar & Apr & Mei & Jun & Jul & Agt & Sep & Okt & Nov & Des \\
\hline
\end{tabular} \begin{tabular}{|l|c|c|c|c|c|c|c|c|c|c|c|c|c|}
\hline RH max & 87,60 & 90,10 & 89,60 & 87,10 & 84,20 & 81,80 & 79,40 & 78,40 & 77,80 & 78,50 & 83,80 & 87,20 \\
\hline
\end{tabular} \begin{tabular}{|l|l|l|l|l|l|l|l|l|l|l|l|l|l|}
\hline Rs (mm/hr) & 6,309 & 6,168 & 6,539 & 6,721 & 6,655 & 6,551 & 6,735 & 7,437 & 7,952 & 7,996 & 7,458 & 7,050 \\
\hline
\end{tabular} \begin{tabular}{|l|l|l|l|l|l|l|l|l|l|l|l|l|}
\hline Ud (m/dt) & 2,389 & 2,583 & 2,111 & 1,667 & 1,667 & 1,722 & 1,778 & 2,000 & 2,167 & 1,722 & 1,472 & 1,972 \\
\hline
\end{tabular} \begin{tabular}{|l|l|l|l|l|l|l|l|l|l|l|l|l|}
\hline c & 1,007 & 1,050 & 1,021 & 1,036 & 1,034 & 1,030 & 1,034 & 1,051 & 1,066 & 1,071 & 1,023 & 1,040 \\
\hline
\end{tabular}

Sumber : Hasil Analisis, 2018

\section{Evapotranspirasi potensial \\ $\mathrm{E}_{\mathrm{To}_{0}}{ }^{*}=\mathrm{W}\left(0,75^{\star} \mathrm{Rn}\right)+(1-\mathrm{W})^{\star} \mathrm{f}(\mathrm{U})^{\star}($ ea-ed $)$ \\ $=0,7222\left(0,75^{\star} 7,2671\right)+(1-$ $, 7222)^{*} 0,29 *(28,47-24,94)$}

Tabel 11 : PerhitunganEvapotranspirasi Potensial

$=3,9362+0,28438=4,22058$

$\mathrm{E}_{\mathrm{To}}=\mathrm{C}^{*} \mathrm{E}_{\mathrm{To}_{\mathrm{o}}}{ }^{*}$

$=1,007 * 4,22058$

$=4,250 \mathrm{~mm} / \mathrm{hr}$

Perhitungan selanjutnya ditabelkan sebagai berikut

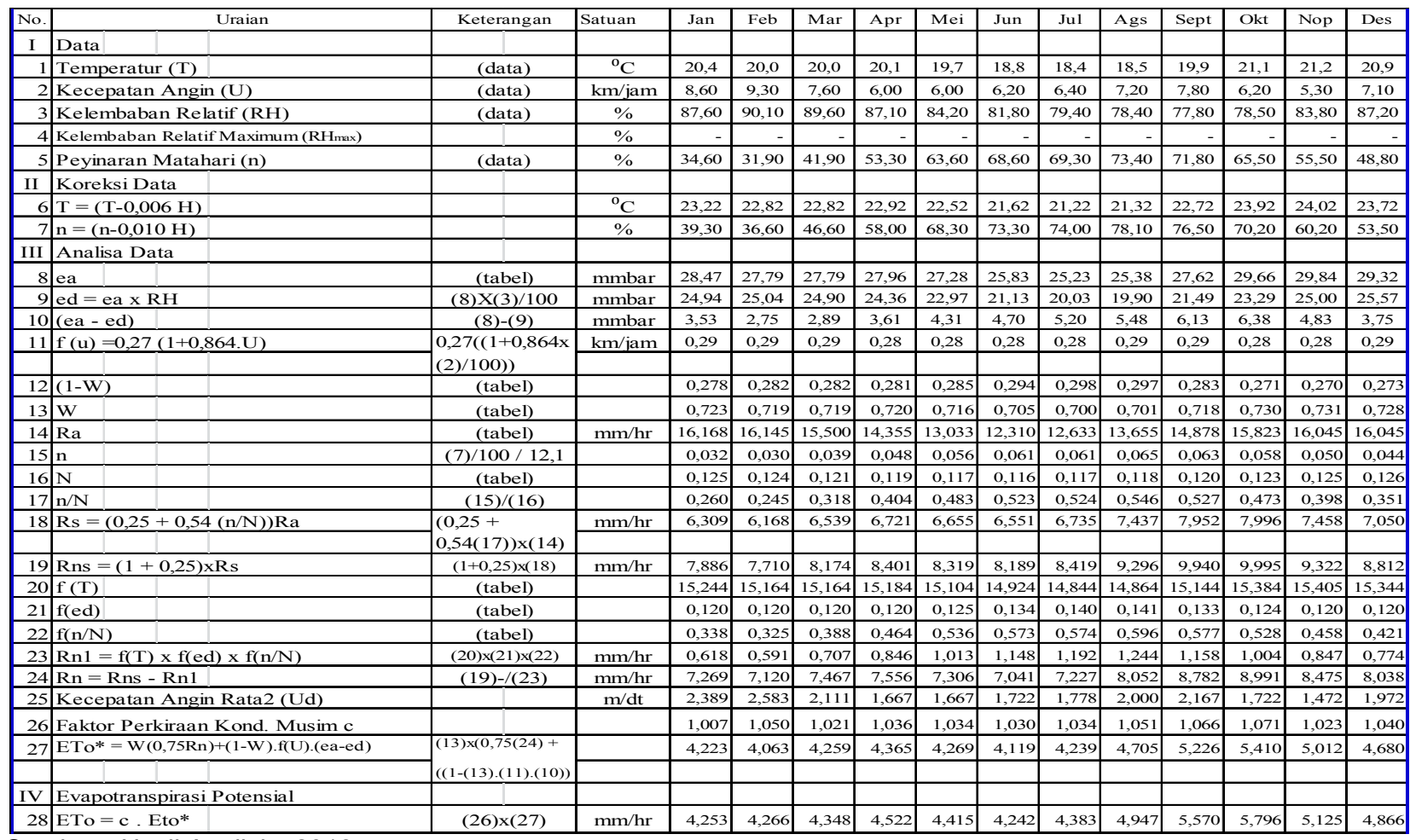

Sumber : Hasil Analisis, 2018

\section{Perkolasi}

Hasil pengamatan yang ada, areal lokasi berupa tanah lempung berpasir, dengan demikian perkolasi dipakai $2 \mathrm{~mm} /$ hari.

Koefisien tanaman (Kc)

Nilai koefisien tanaman (Kc) tergantung pada jenis tanaman dan pertumbuhan tanaman. Dalam perhitungan ini koefisien tanaman yang digunakan untuk padi dengan varietas reguler mengikuti ketentuan Nedeco / Prosida.

\section{Curah hujan efektif}

Curah hujan (Re) dihitung dari data curah hujan rata-rata setengahbulanan yang selanjutnya diurutkan dari data terkecil hingga terbesar. Metodeyang digunakan untuk menghitung curah hujan efektif adalah Perhitungan curah hujan andalan ( $\left.\mathbf{R}_{80}\right)$

Curah hujan andalan adalah jumlah $\mathrm{CH}$ yang dapat diharapkan ada (andal) pada periode tertentu di suatu tanah, di mana risiko kegagalan telah dihitung dengan benar. 


$$
R_{80}=\frac{n}{5}+1
$$

Tabel 12.Curah hujan efektif untuk tanaman padi

\begin{tabular}{|c|c|c|c|c|c|}
\hline Bulan & Uraian & $R_{80}$ & Re Padi $(70 \% *$ R 80$)$ & $\mathrm{Hr} 1 / 2$ bln & Re Padi $(\mathrm{mm} / \mathrm{hr})$ \\
\hline \multirow{2}{*}{ Januari } & 1 & 74,45 & 52,12 & 15 & 3,47 \\
\hline & 2 & 125,00 & 87,50 & 16 & 5,47 \\
\hline \multirow{2}{*}{ Februari } & 1 & 80,00 & 56,00 & 15 & 3,73 \\
\hline & 2 & 60,00 & 42,00 & 13 & 3,23 \\
\hline \multirow{2}{*}{ Maret } & 1 & 222,00 & 155,40 & 15 & 10,36 \\
\hline & 2 & 234,00 & 163,80 & 16 & 10,24 \\
\hline \multirow{2}{*}{ April } & 1 & 224,00 & 156,80 & 15 & 10,45 \\
\hline & 2 & 227,00 & 158,90 & 15 & 10,59 \\
\hline \multirow{2}{*}{ Mei } & 1 & 125,00 & 87,50 & 15 & 5,83 \\
\hline & 2 & 123,00 & 86,10 & 16 & 5,38 \\
\hline \multirow{2}{*}{ Juni } & 1 & 132,00 & 92,40 & 15 & 6,16 \\
\hline & 2 & 93,00 & 65,10 & 15 & 4,34 \\
\hline \multirow{2}{*}{ Juli } & 1 & 115,00 & 80,50 & 15 & 5,37 \\
\hline & 2 & 83,00 & 58,10 & 16 & 3,63 \\
\hline \multirow{2}{*}{ Agustus } & 1 & 73,50 & 51,45 & 15 & 3,43 \\
\hline & 2 & 118,50 & 82,95 & 16 & 5,18 \\
\hline \multirow{2}{*}{ September } & 1 & 97,00 & 67,90 & 15 & 4,53 \\
\hline & 2 & 103,50 & 72,45 & 15 & 4,83 \\
\hline \multirow{2}{*}{ Oktober } & 1 & 35,00 & 24,50 & 15 & 1,63 \\
\hline & 2 & 15,00 & 10,50 & 16 & 0,66 \\
\hline \multirow{2}{*}{ November } & 1 & 228,00 & 159,60 & 15 & 10,64 \\
\hline & 2 & 235,00 & 164,50 & 15 & 10,97 \\
\hline \multirow{2}{*}{ Desember } & 1 & 227,00 & 158,90 & 15 & 10,59 \\
\hline & 2 & 127,00 & 88,90 & 16 & 5,56 \\
\hline
\end{tabular}

Sumber : Hasil Analisi, 2018

\section{Kebutuhan Air Untuk Irigasi}

Yaitu kebutuhan air yang digunakan untuk menentukan pola tanaman untuk menentukan tingkat efisiensi saluran irigasi sehingga didapat kebutuhan air untuk masing-masing jaringan (Ditjen Pengairan, 1985). Perhitungan kebutuhan air irigasi ini dimaksudkan untuk menentukan besarnya debit yang akan dipakai untuk mengairi daerah irigasi..

Tabel 14 .Perhitungan Kebutuhan Air Untuk Penyiapan Lahan

\begin{tabular}{|c|c|c|c|c|c|c|c|c|c|c|c|c|c|c|}
\hline \multirow{2}{*}{ No. } & \multirow{2}{*}{ Parameter } & \multirow{2}{*}{ Satuan } & \multicolumn{12}{|c|}{ Bulan } \\
\hline & & & Jan & $\mathrm{Feb}$ & Mar & Apr & Mei & Jun & \begin{tabular}{|l|l|} 
Jul \\
\end{tabular} & $\mathrm{Ags}$ & Sept & $0 \mathrm{kt}$ & Nop & Des \\
\hline 1 & Eto & mm hari & 4,25 & 4,27 & 4,35 & 4,52 & 4,41 & 4,24 & 4,38 & 4,95 & 5,57 & 5,80 & 5,13 & 4,87 \\
\hline 2 & E0 & mmhari & 4,68 & 4,69 & 4,78 & 4,97 & 4,86 & 4,67 & 4,82 & 5,44 & 6,13 & 6,38 & 5,64 & 5,35 \\
\hline 3 & $P$ & mm/hari & 2 & 2 & 2 & 2 & 2 & 2 & 2 & 2 & 2 & 2 & 2 & 2 \\
\hline 4 & M & mmlhari & 6,68 & 6,69 & 6,78 & 6,97 & 6,86 & 6,67 & 6,82 & 7,44 & 8,13 & 8,38 & 7,64 & 7,35 \\
\hline 5 & $T$ & hari & 45 & 45 & 45 & 45 & 45 & 45 & 45 & 45 & 45 & 45 & 45 & 45 \\
\hline 6 & $S$ & $\mathrm{~mm}$ & 300 & 300 & 300 & 300 & 300 & 300 & 300 & 300 & 300 & 300 & 300 & 300 \\
\hline 7 & k & & 1,00 & 1,00 & 1,02 & 1,05 & 1,03 & 1,00 & 1,02 & 1,12 & 1,22 & 1,26 & 1,15 & 1,10 \\
\hline 8 & IR & mm/hari & 10,55 & \begin{tabular}{|l|}
10,56 \\
\end{tabular} & \begin{tabular}{|l|}
10,62 \\
\end{tabular} & \begin{tabular}{|l|}
10,75 \\
\end{tabular} & \begin{tabular}{|l|}
10,67 \\
\end{tabular} & 10,55 & 10,65 & 11,07 & \begin{tabular}{|l|}
11,54 \\
\end{tabular} & \begin{tabular}{|l|}
11,71 \\
\end{tabular} & \begin{tabular}{|l|}
11,20 \\
\end{tabular} & 11,01 \\
\hline
\end{tabular}

Sumber : Hasil Perhitungan, 2018

Direncanakan pola tata tanam padi - padi palawija, dengan jenis padi varietas unggul dan palawija tanaman kedelai. Kebutuhan air Irigasi pada DAS Wae Bobo dengan pola tanam Padi -

Padi - Palawija.
Tabel 13 Curah hujan efektif untuk tanaman palawija

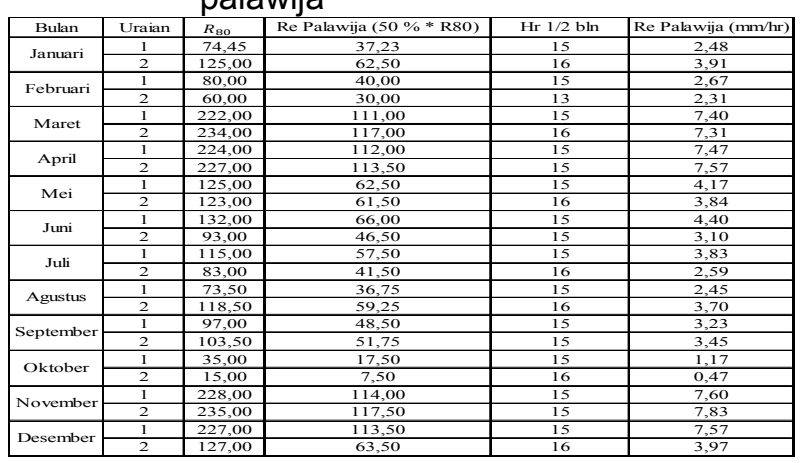

Sumber : Hasil Analisi, 2018

Tabel 15: Kebutuhan Air Irigasi Musim Tanam November 1, Maret 2 dan Juli 1

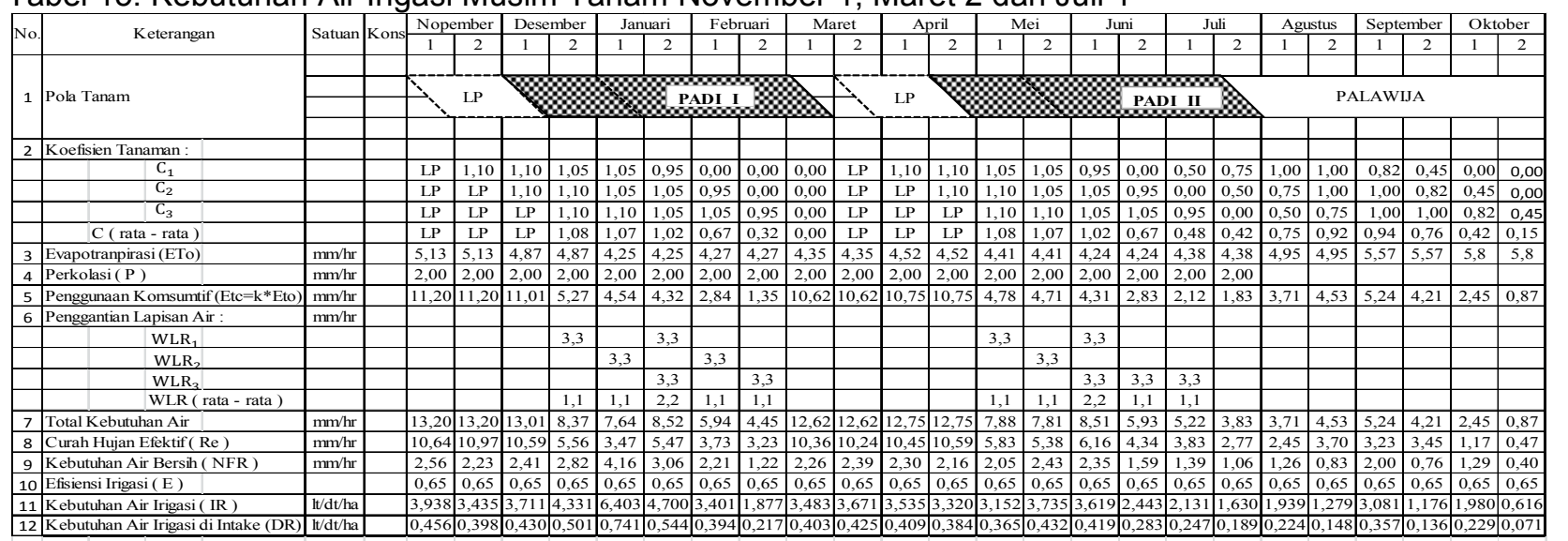

Sumber : Hasil Analisis, 2018

Tabel 16 .Kebutuhan Air Irigasi Musim Tanam November 2, April1 dan Juli 2 


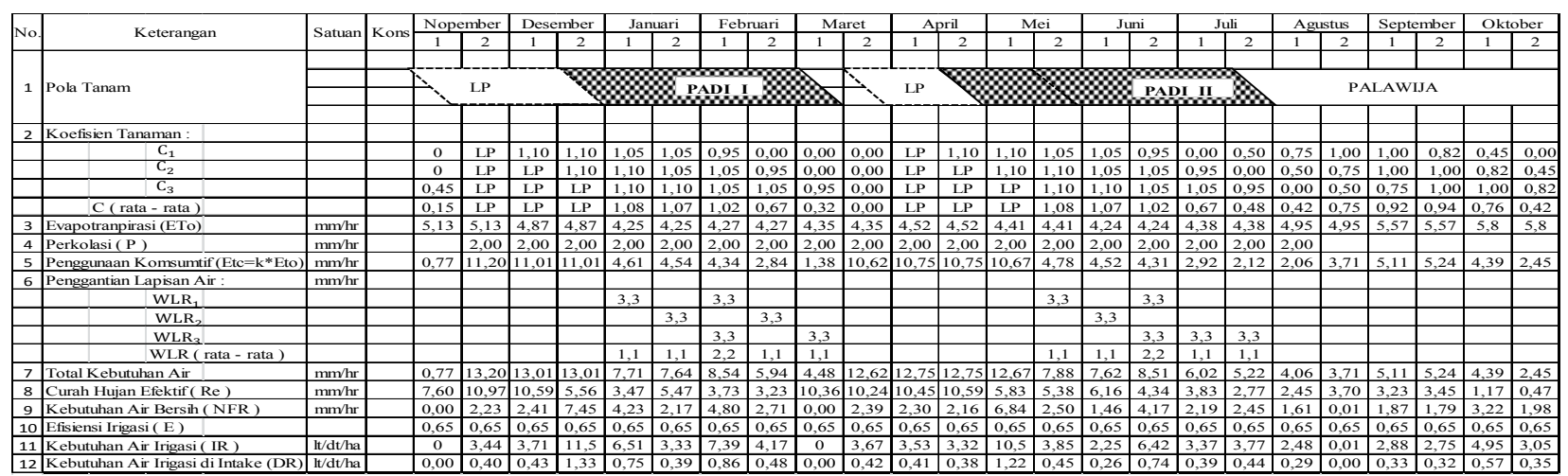

Sumber : Hasil Analisis, 2018

Tabel 17.Kebutuhan Air Irigasi Musim Tanam Desember 1, April2,dan Agustus 1

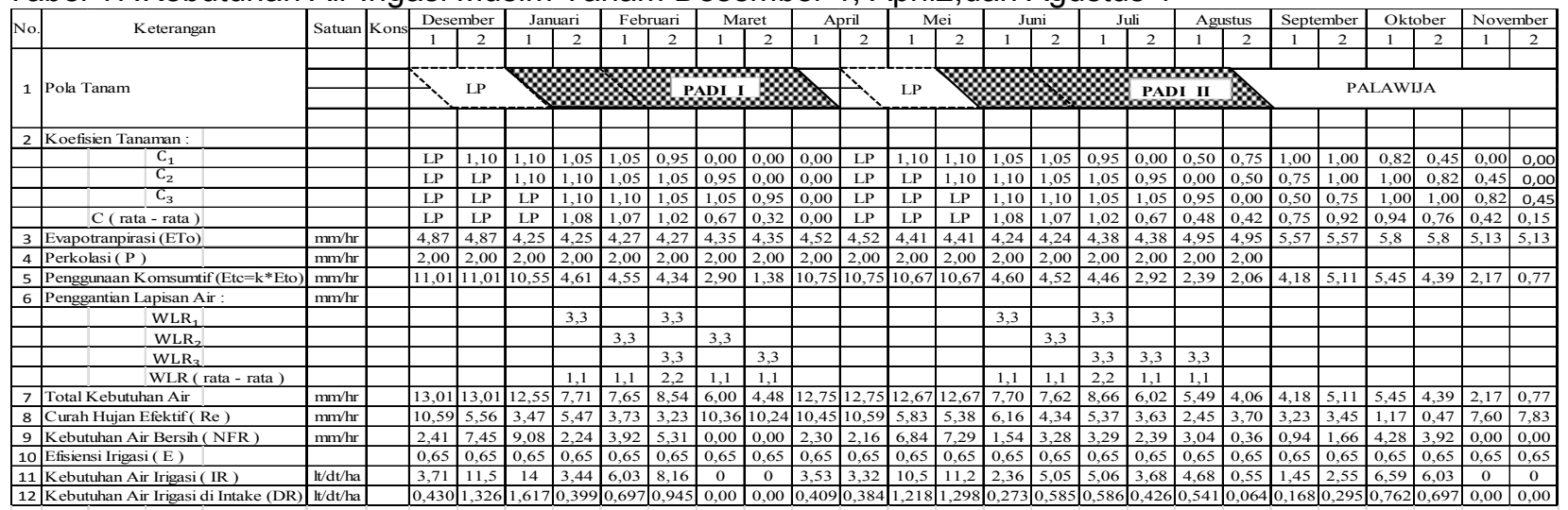

Sumber : Hasil Analisis, 2018

Tabel 18 .Kebutuhan Air Irigasi Musim Tanam Desember 2, Mei 1,dan Agustus 2

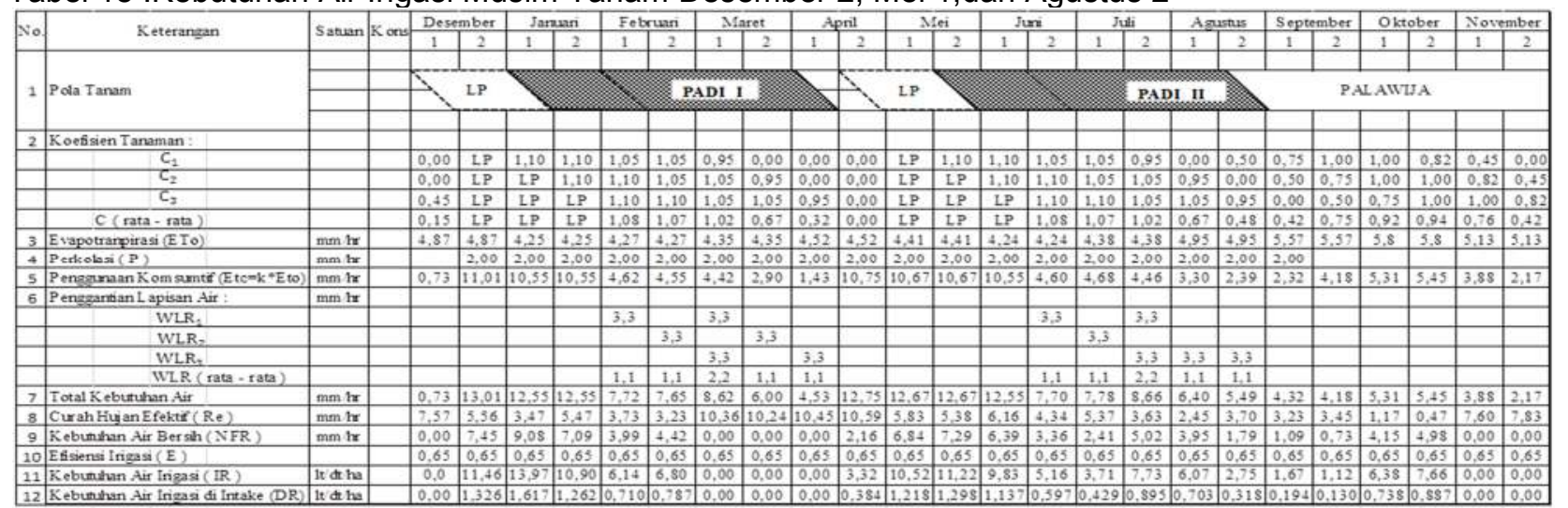

Sumber : Hasil Analisis, 2018

Tabel 19.Kebutuhan Air Irigasi Musim Tanam Januari 1, Mei 2,dan September 1 


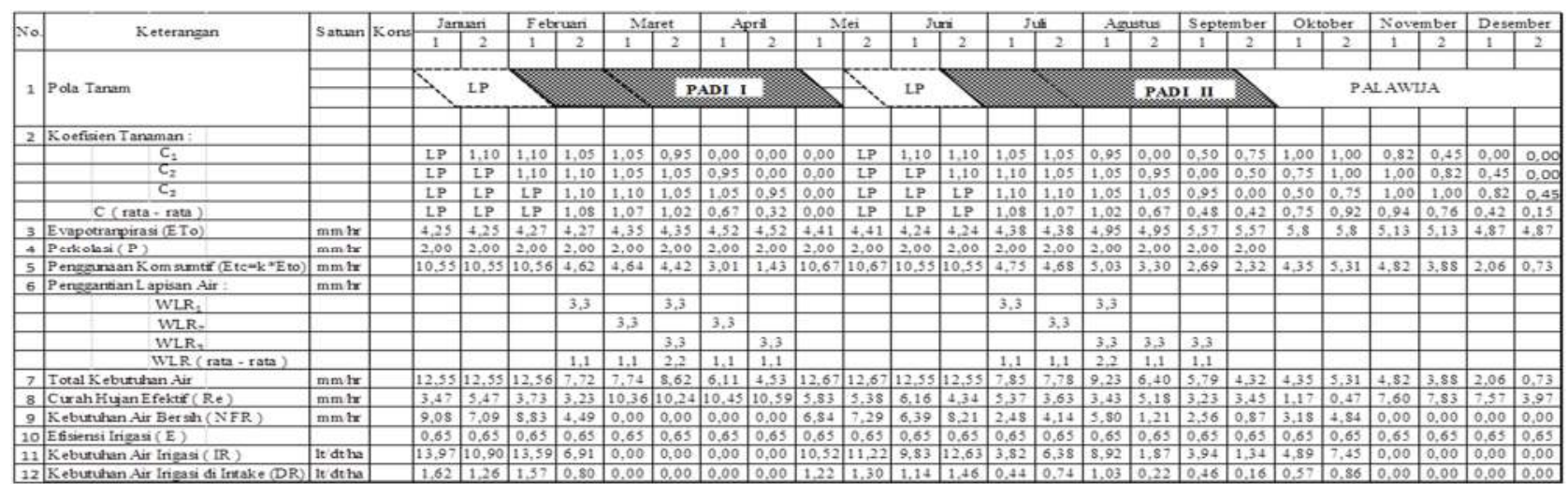

Sumber : Hasil Analisis, 2018

Tabel 20.Kebutuhan Air Irigasi Musim Tanam Januari 2, Juni 1,dan September 2

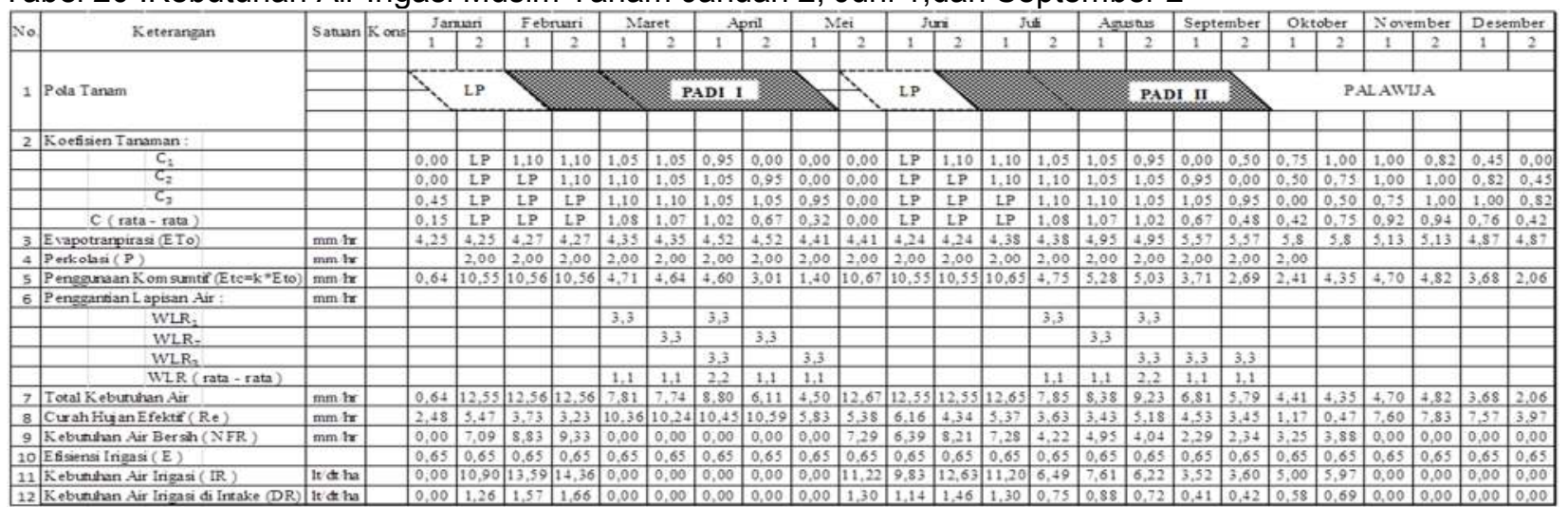

Sumber : Hasil Analisis, 2018

Tabel 21: Perhitungan Debit ketersediaan Air di DAS Wae Bobo

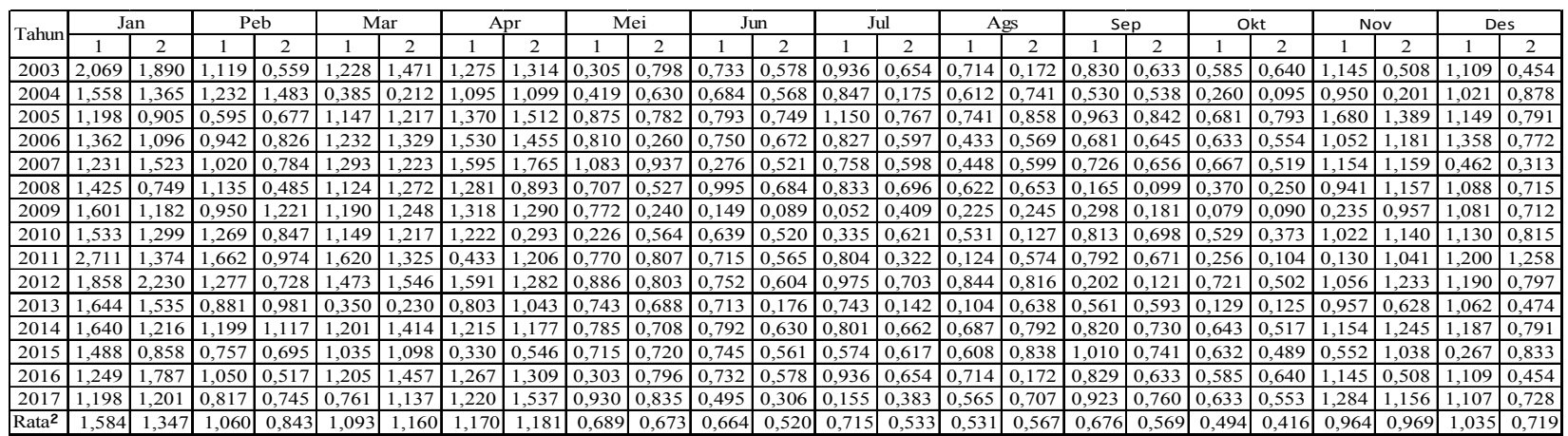

Sumber : Hasil Analisis, 2018

Tabel 22 : Debit Andalan ( Q80) pada DAS Wae Bobo

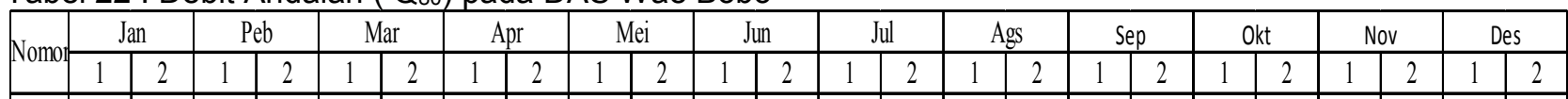

\begin{tabular}{lllllllllllllllllllllllllllll}
1,2310 & 0,0049 & 0,8169 & 0,5587 & 0,7611 & 1,0977 & 0,8034 & 0,8926 & 0,3054 & 0,5273 & 0,4952 & 0,3058 & 0,3353 & 0,3217 & 0,2254 & 0,1723 & 0,2984 & 0,1814 & 0,2556 & 0,1043 & 0,5519 & 0,5082 & 1,0212 & 0,4536 \\
\hline
\end{tabular}

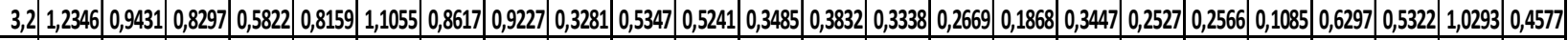

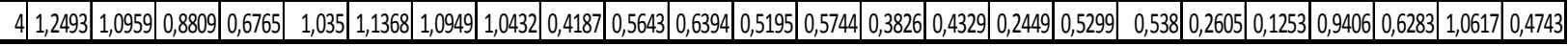

Sumber : Hasil Analisis, 2018

\section{Neraca Air}

Neraca air (water balance) merupakan neraca masukan dan keluaran air di suatu tempat pada periode tertentu, sehingga dapat diketahui jumlah air tersebut kelebihan (surplus) ataupun kekurangan (defisit). Dalam perhitungan digunakan satuan tinggi air ( $\mathrm{mm}$ atau $\mathrm{cm}$ ). Satuan waktu yang digunakan dapat dipilih satuan harian, mingguan, dekade (10harian), bulanan ataupun tahunan sesuai dengan keperluan (Gede,
2009).Neraca air ketersediaan dan kebutuhan, Persamaan 2.102 s/d persamaan 2.108 meliputi :

a. Analisis neraca air dengan simulasi Mock Dr. F.J. Mock (1973) memperkenalkan model sederhana simulasi keseimbangan air bulanan untuk aliran yang meliputi data hujan, evaporasi dan karakteristik hidrologi daerah pengaliran. Model neraca air Dr.Mock menyediakan metode perhitungan yang relatif sederhana untuk berbagai komponen berdasarkan penelitian DAS 
Pemanfaatan Air Daerah Aliran Sungai (Das) Wae Bobo Untuk Memenuhi Kebutuhan Air Irigasi 35

Guna Meningkatkan Hasil Pertanian Di Kabupaten Manggarai Timur Provinsi Nusa Tenggara

Timur

Joko Suparmanto ${ }^{1 *}$, Sutirto ${ }^{2}$

di seluruh Indonesia. Curah hujan rata-rata bulanan di daerah aliran sungai dihitung dari curah hujan aktual dan data pengukuran evapotranspirasi di daerah aliran sungai dari data meteorologi (rumus Penman) dan karakteristik vegetasi.. Perhitungan pada tabel $30 \mathrm{~s} / \mathrm{d}$ tabel 32

b. Evapotranspirasi aktual (Ea) dan Evapotranspirasi Terbatas (ET)

Evapotranspirasi aktual dari Evaporasi potensial metode Penman (ETo). Hubunganantara evaporasi potensial dengan evapotranspirasi aktual.Perhitungan pada tabel $5.35 \mathrm{~s} / \mathrm{d}$ tabel 5.36

Tabel 45. Water Balance DAS Wae Bobo Musim Tanam November 1 Maret 2 dan Juli 1

Tabel 45. Water Balance DAS Wae Bobo Musim Tanam November 1 Maret 2 dan Juli 1

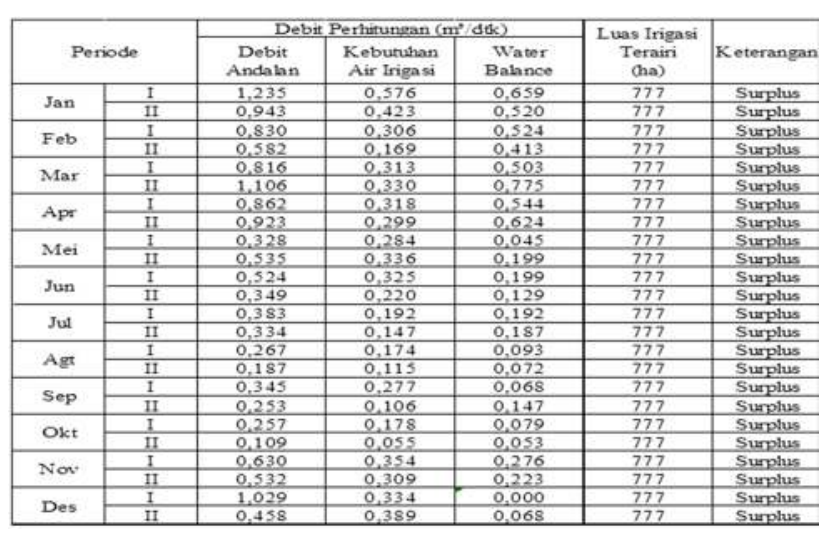

Sumber : Hasil Analisis, 2018

Tabel 46. Water Balance DAS Wae Bobo Musim Tanam November 2 April 1 dan Juli 2

\begin{tabular}{|c|c|c|c|c|c|c|}
\hline \multirow{2}{*}{\multicolumn{2}{|c|}{ Periode }} & \multicolumn{3}{|c|}{ Debit Perhitungan $\left(\mathrm{m}^{3} / \mathrm{dok}\right)$} & \multirow{3}{*}{\begin{tabular}{|c}
$\begin{array}{c}\text { Luas Irigasi } \\
\text { Teraini } \\
\text { (ha) }\end{array}$ \\
777 \\
\end{tabular}} & \multirow{4}{*}{\begin{tabular}{|c} 
Keterangan \\
Surplus \\
Surplus
\end{tabular}} \\
\hline & & Debit & Kebutuhan & Water & & \\
\hline & & 1,235 & $\frac{\text { Adr hinas }}{0,586}$ & $\frac{\text { Balance }}{0,649}$ & & \\
\hline Jan & & 0,943 & 0,300 & 0,643 & & \\
\hline $\mathrm{Feb}$ & & 0,830 & 0,665 & 0,165 & 777 & Surplus \\
\hline Fed & & 0,582 & 0,375 & 0,207 & 777 & Surplus \\
\hline Mar & & $\frac{0,816}{1,106}$ & $\frac{0,000}{0,330}$ & $\frac{0.816}{0.775}$ & $\frac{7777}{777}$ & $\begin{array}{l}\text { Surplus } \\
\text { Surphlus }\end{array}$ \\
\hline & & 0.862 & 0,318 & 0.544 & 777 & Surplus \\
\hline Apr & & 0.923 & 0,299 & 0,624 & 777 & Surplus \\
\hline Mei & & 0,328 & 0,946 & $\frac{-0,618}{0.180}$ & 508 & Defist \\
\hline & & $\frac{0,535}{0,524}$ & $\frac{0,346}{0,203}$ & $\frac{0.189}{0.321}$ & $\frac{777}{777}$ & $\begin{array}{l}\text { Surplus } \\
\text { Surplus }\end{array}$ \\
\hline Jun & & 0,349 & 0,577 & $-0,229$ & 308 & Defisit \\
\hline Jul & & 0,383 & $\frac{0.303}{0.330}$ & 0,080 & $\frac{777}{12}$ & Surplus \\
\hline & & $\frac{0,334}{0.267}$ & $\frac{0,339}{0,223}$ & $\frac{-0,005}{0,044}$ & $\frac{12}{777}$ & $\begin{array}{l}\text { Defisit } \\
\text { Surplus }\end{array}$ \\
\hline Agt & & 0,187 & 0,001 & 0,18 & 777 & Surplus \\
\hline Sep & & 0,345 & 0,259 & 0,08 & 777 & Surplus \\
\hline & & $\frac{0.253}{0.257}$ & $\frac{0,247}{0.445}$ & $\frac{0,006}{-0.180}$ & $\frac{777}{329}$ & $\begin{array}{l}\text { Surplus } \\
\text { Defisit }\end{array}$ \\
\hline Okt & & 0.109 & 0.275 & -0.166 & 470 & Defisit \\
\hline Nov & & $\frac{0.630}{0.532}$ & $\frac{0.000}{0.309}$ & $\frac{0.630}{0.223}$ & $\frac{777}{777}$ & $\begin{array}{l}\text { Surplus } \\
\text { Surpolus }\end{array}$ \\
\hline & & & 0.334 & 0,696 & 777 & Surplus \\
\hline Des & $\overline{\mathrm{n}}$ & 0.458 & 1.031 & -0.577 & 0 & Defist \\
\hline
\end{tabular}

Sumber : Hasil Analisis, 2018

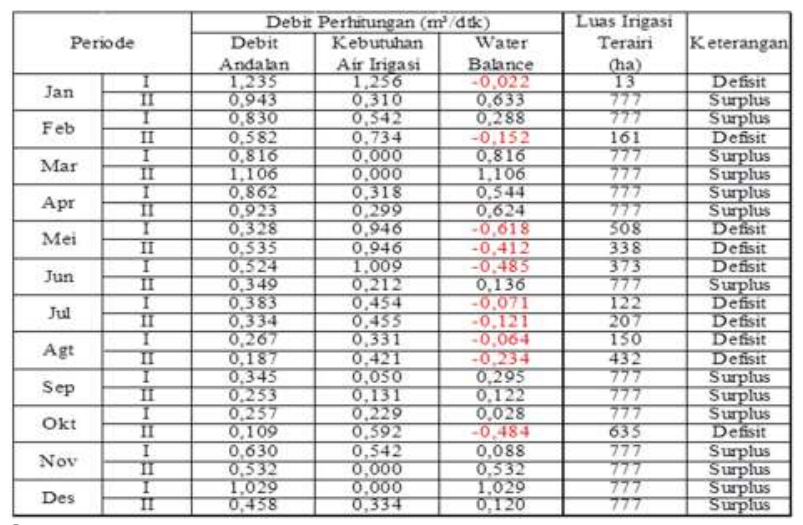

Sumber : Hasil Analisis, 2018

Tabel 46 Water Balance DAS Wae Bobo Musim Tanam Desember 2, Mei 1,Agustus

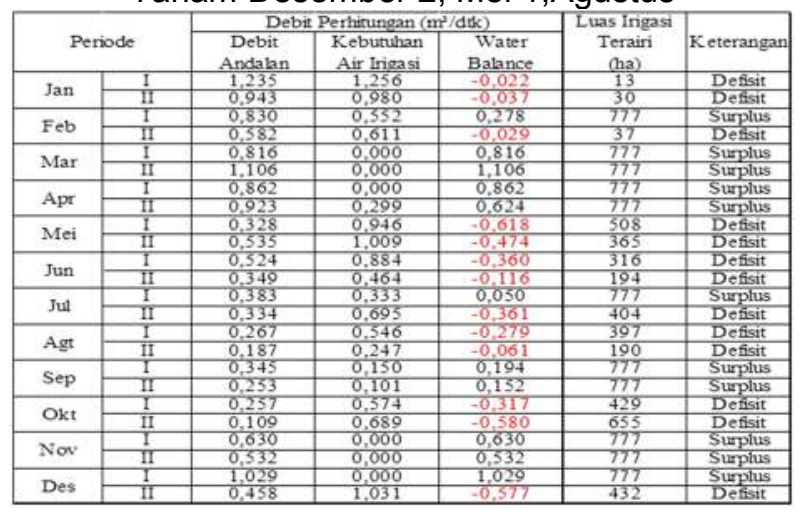

Sumber : Hasil Analisis, 201

Tabel 46 Water Balance DAS Wae Bobo Musim Tanam Januari 1, Mei 2,September 1

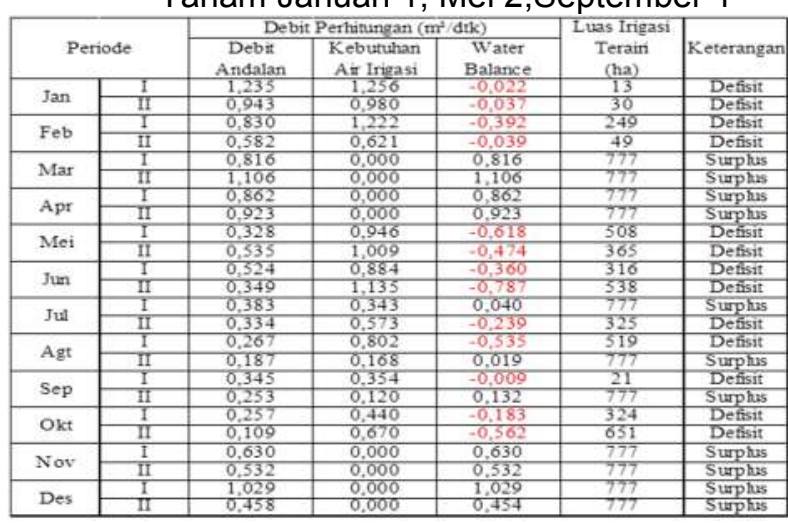

Sumber : Hasil Analisis, 2018

Tabel 47 Water Balance DAS Wae Bobo Musim Tanam Januari 2, Juni1,September 2 


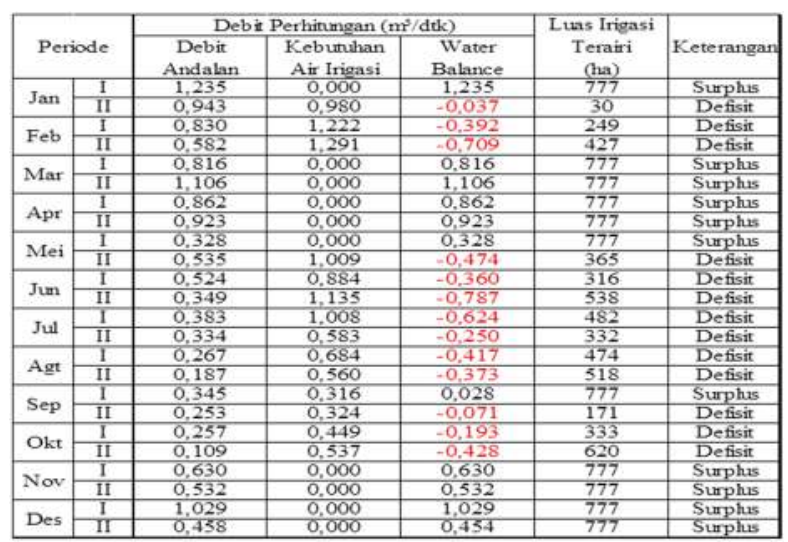

Sumber : Hasil Analisis, 2018

Tabel 48 .Kebutuhan Air Irigasi di Intake untuk setiap Daerah Irigasi pada DAS Wae Bobo

\begin{tabular}{|c|c|c|c|c|c|c|c|c|c|c|c|c|c|c|c|c|c|c|c|c|c|c|c|c|c|c|}
\hline \multirow{2}{*}{ No. } & \multirow{2}{*}{ Uraian } & \multirow{2}{*}{ Satuan } & \multicolumn{2}{|c|}{ Janari } & \multicolumn{2}{|c|}{ Fetnari } & \multicolumn{2}{|c|}{ Maret } & \multicolumn{2}{|c|}{ Apri } & \multicolumn{2}{|c|}{ Mei } & \multicolumn{2}{|c|}{ Juni } & \multicolumn{2}{|c|}{ Jut } & \multicolumn{2}{|c|}{ Agustus } & \multicolumn{2}{|c|}{ September } & \multicolumn{2}{|c|}{ Oktober } & \multicolumn{2}{|c|}{ Novembar } & \multicolumn{2}{|c|}{ Desember } \\
\hline & & & 1 & 2 & 1 & 2 & 1 & 2 & 1 & 2 & 1 & 2 & 1 & 2 & 1 & 2 & 1 & 2 & 1 & 2 & 1 & 2 & 1 & 2 & 1 & 2 \\
\hline 1 & Kebuninn Air Irigas di intake (DR) & Itdtha & 0,741 & 0,544 & 0.394 & 0,217 & 0,403 & 0,425 & 0,409 & 0,384 & 0,365 & 0,432 & 0,419 & 0,283 & 0,247 & 0,189 & 0,224 & 0,148 & 0,35 & 0,136 & 0,229 & 0,071 & 0,456 & 0,398 & 0,430 & 0,50 \\
\hline 2 & Dt. Wae Bobo Racang I : 195 ha & $\mathrm{m}^{3} \mathrm{ddk}$ & 0,145 & 0,106 & 0,077 & 0,042 & 0,079 & 0,083 & 0,080 & 0,075 & 0,071 & 0,084 & 0,082 & 0,055 & 0,048 & 0,037 & 0,044 & 0,029 & 0,07 & 0,027 & 0,045 & 0,01 & 0,089 & 0,07 & 0,08 & 0,098 \\
\hline 3 & DI. Wae Bobo Racarg II : $100 \mathrm{ha}$ & $m^{3} d t$ & 0.074 & 0,054 & 0,039 & 0,022 & 0,040 & 0,042 & $0,0+1$ & 0,038 & 0,036 & $0,0+3$ & 0,042 & 0,028 & 0,025 & 0,019 & 0,022 & 0,015 & 0,036 & 0,014 & 0,023 & 0,00 & 0,046 & $0,040]$ & 0,045 & 0,05 \\
\hline 4 & DL. Wae Bobo Mura : 117 ha & $\mathrm{m}^{\mathrm{s}} \mathrm{dtk}$ & 0,087 & 0,064 & 0,046 & 0,025 & 0,047 & 0,050 & 0,048 & 0,045 & $0,043 \mid$ & 0,051 & 0,049 & 0,033 & 0,029 & 0,022 & 0,026 & 0,017 & 0,042 & 0,016 & 0,027 & 0,008 & 0,053 & 0,047 & 0,050 & 0,059 \\
\hline 5 & DL. Wae Bobo Mura II: 85 ha & $\mathrm{m}^{\mathrm{s}} \mathrm{dtk}$ & 0,063 & 0,046 & 0,033 & 0,018 & 0,034 & 0,036 & 0,035 & 0,033 & 0,031 & 0,037 & 0,036 & 0,024 & 0,021 & 0,016 & 0,019 & {$[0,0$.} & 0,030 & 0,012 & 0,019 & 0,006 & 0,03 & {$[0,0$,} & 0,03 & 0,04 \\
\hline 6 & DL. Wae Bobo III Lolang: $50 \mathrm{hm}$ & $m^{3} d d^{-}$ & 0.037 & 0,027 & 0,020 & 0.011 & 0,020 & 0,021 & 0,020 & 0,019 & 0,018 & 0,022 & 0,021 & 0,014 & 0,012 & 0,009 & 0,011 & 0,007 & 0,018 & 0,007 & 0,011 & 0.004 & 0,023 & 0,020 & 0,021 & 0,02 \\
\hline 7 & DI. Wae Bobo II : 80 ha & $\mathrm{m}^{3} \mathrm{ddk}$ & 0.059 & 0,044 & 0,031 & 0,017 & 0,032 & 0,034 & 0,033 & 0,031 & 0,029 & 0,035 & 0.034 & 0,023 & 0,020 & 0,015 & 0,018 & 0,012 & 0,029 & 0,011 & 0,018 & 0,006 & 0,036 & 0,032 & 0,034 & 0,04 \\
\hline 8 & DI. Wae Bobo : 150 ha & $m^{3} d d^{2}$ & 0,111 & 0,082 & 0,059 & 0,033 & 0,060 & 0,064 & 0,061 & 0,058 & 0,055 & 0,065 & 0,063 & 0,042 & 0,037 & 0.028 & 0,034 & 0,022 & 0,053 & 0,020 & 0,034 & 0,01 & 0,068 & 0,06 & 0,06 & 0,07 \\
\hline & & $m^{3} d d^{2}$ & 0,576 & 0,423 & 0,306 & 0,169 & 0,313 & 0,330 & 0,318 & 0.299 & 0,284 & 0.336 & 0,325 & 0,220 & 0,192 & 0,147 & 0,174 & 0,115 & 0.277 & 0,106 & 0,178 & 0,055 & 0,354 & 0,309 & 0,334 & 0,38 \\
\hline
\end{tabular}

Sumber : Hasil Analisis, 2018

Tabel 48 .Debit Ketersediaan Air, Kebutuhan Air Irigasi dan Water Balance pada DAS Wae Bobo

\begin{tabular}{|c|c|c|c|c|c|c|c|c|c|c|c|c|c|c|c|c|c|c|c|c|c|c|c|c|c|}
\hline \multirow{2}{*}{ No. } & \multirow{2}{*}{ Uraian } & \multirow{2}{*}{ Satuan } & \multicolumn{2}{|c|}{ Januari } & \multicolumn{2}{|c|}{ Februari } & \multicolumn{2}{|c|}{ Maret } & \multicolumn{2}{|c|}{ April } & \multicolumn{2}{|c|}{ Mei } & \multicolumn{2}{|c|}{ Juni } & \multicolumn{2}{|c|}{ Juli } & \multicolumn{2}{|c|}{ Agustus } & \multicolumn{2}{|c|}{ September } & \multicolumn{2}{|c|}{ Oktober } & November & \multicolumn{2}{|c|}{ Desember } \\
\hline & & & 1 & 2 & 1 & 2 & 1 & 2 & 1 & 2 & 1 & 2 & 1 & 2 & 1 & 2 & 1 & 2 & 1 & 2 & & 2 & \begin{tabular}{l|l}
1 & 2 \\
\end{tabular} & 1 & 2 \\
\hline 1 & Ketersediaan Air & $\mathrm{m}^{3} / \mathrm{dtk}$ & 1,235 & 0,943 & 0,830 & 0,582 & 0,8161 & 1,106 & 0,862 & 0,923 & 0,3280 & 0,535 & 0,5240 & 0,349 & 0,383 & 0,334 & 0,267 & 0,187 & 0,3450 & 0,253 & $0,257 \mid 0$ &, 1090 & $0,630 \mid 0,5$ & 1,029 & 0,458 \\
\hline 2 & Kebutuhan Air rrigasi & $\mathrm{m}^{3} / \mathrm{dtk}$ & 0,576 & 0,423 & 0,306 & 0,1690 & $\begin{array}{lll}0,313 & 0 \\
\end{array}$ & 0,330 & 0,318 & 0,299 & 0,2840 & 0,3360 & 0,3250 & 0,220 & 0,192 & 0,147 & 0,174 & 0,115 & 0,2770 & 0,1060 & 0,1780 & 0,0550 & & 0,334 & 0,389 \\
\hline 3 & Water Balance & $\mathrm{m}^{3} / \mathrm{dtk}$ & 0,6590 & 0,520 & 0,524 & 0,4130 & \begin{tabular}{c|c}
0,503 & 0 \\
\end{tabular} & 0,775 & 0,544 & 0,624 & 0,045 & 0,199 & $0,199 \mid 0$ & 0,129 & 0,192 & 0,187 & 0,093 & 0,072 & 0,0680 & 0,1470 & $\begin{array}{l}0,079 \\
0,\end{array}$ &, 05310 & $0,2760,2$ & 30,696 & 0,068 \\
\hline
\end{tabular}

Sumber : Hasil Analisis, 2018 
Pemanfaatan Air Daerah Aliran Sungai (Das) Wae Bobo Untuk Memenuhi Kebutuhan Air Irigasi Guna Meningkatkan Hasil Pertanian Di Kabupaten Manggarai Timur Provinsi Nusa Tenggara

Joko Suparmanto ${ }^{1 *}$, Sutirto ${ }^{2}$

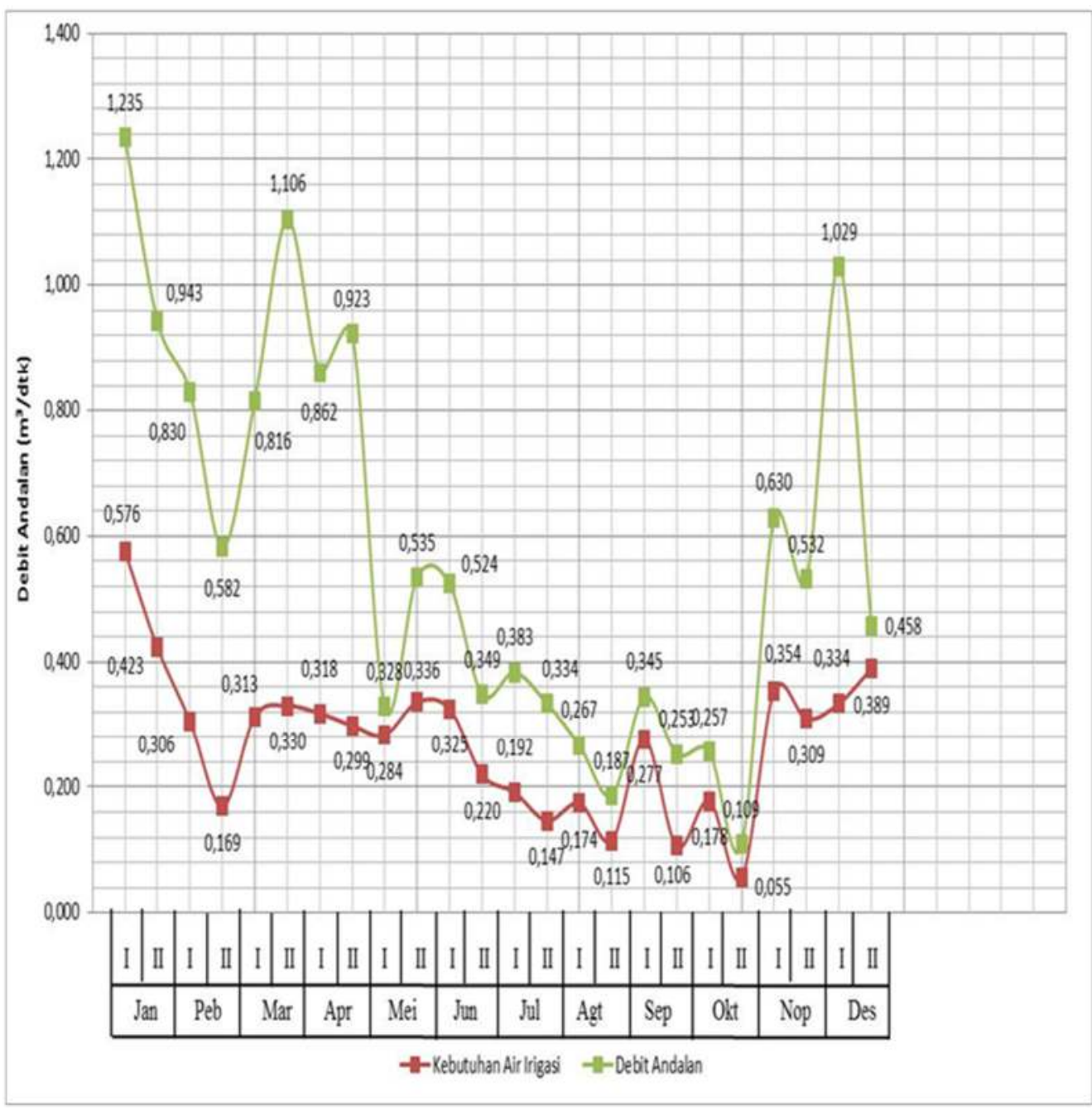

Gambar 5 Water Balance DAS Wae Bobo

Sumber : Hasil Analisis, 2018

\section{Kesimpulan}

Berdasarkan hasil análisis pembahasan pada Bab $\mathrm{V}$, maka dapat diambil kesimpulan sebagai berikut :

a. Debit ketersediaan air aliran Sungai Wae Bobo yang terbesar terjadi pada pada bulan Januari 1 sebesar $=1,584 \mathrm{~m}^{3} / \mathrm{dtk}$, yang terkecil terjadi pada bulan Oktober $2=$ sebesar $0,416 \mathrm{~m}^{3} / \mathrm{dtk}$. Debit ketersediaan air aliran Sungai Wae Bobo untuk debit andalan $\left(Q_{80}\right)$ yang terbesar terjadi pada pada bulan Januari $1=$ sebesar 1,235 $\mathrm{m}^{3} / \mathrm{dtk}$, sedangkan yang terkecil terjadi pada bulan Oktober $2=0,109 \mathrm{~m}^{3} / \mathrm{dtk}$.

b. Kebutuhan air untuk irigasi aliran sungai Wae Bobo terbesar terjadi pada bulan Januari $1=$ $0.576 \mathrm{~m}^{3} / \mathrm{dtk}$ sedangkan yang terkecil pada bulan Oktober $2=0.055 \mathrm{~m}^{3} / \mathrm{dtk}$.

c. Neraca air untuk irigasi pada aliran Sungai Wae Bobo, menjelaskan bahwa pola tanam yang dipilih yaitu padi-padi-palawija dengan periode musim tanam November 1, Maret 2 dan Juli 1 menghasilkan debit balance surplus untuk DAS Wae Bobo dengan total areal irigasi 777 ha.

Saran

Berdasarkan kesimpulan maka disarankan hal-hal sebagai berikut :

a.Dari hasil analisis perhitungan melalui pergeseran pola tanam yang di awali pada bulan November menghasilkan debit air surplus dari DAS Oebobo sekiranya pemerintah dalam hal ini Dinas Pertanian memberikan penyuluhan kepadapara petani untuk diawali musim tanam dengan pola tanam Padi-Padi- Polowijo. Hal tersebut untuk meningkatkan hasil pertanian yang lebih meningkat dari tahun - tahun sebelumnya.

b. Untuk menjaga debit air sungai Wae Bobo terpelihara kuantitasnya, perlu diadakan konservasi tanah dan air di daerah tangkapan air 
guna menjaga sumber - sumber bisa terpilhara dan air tetap terjaga.

Perlunya dibuat perlakuan melalui civil teknis di bagian hulu Daerah Aliran Sungai Wae Bobo dengan dibuatkan parit jebakan air untuk memperkaya kandungan air tanah di bagian hilir.

\section{UCAPAN TERIMAKASIH}

Disadari oleh penulis tentang kekurangan dan keterbatasan yang dimiliki meskipun telah diupayakan segala kemampuan untuk lebih teliti. Untuk itu diharapakan para pembaca bisa memberikan saran-saran yang membangun sebagai masukan karya-karya penulis mendatang. Pada kesempatan ini pula penulis ingin mengungkapkan rasa terima kasih kepada :

Direktur Politeknik Negeri Kupang yang memberikan kesempatan kepada penulis untuk diikutsetakan dalam penelitia Rutin Politeknik Negeri Kupang pada Tahun Anggaran 2018. Dan Kepala Pusat Penelitian dan PpM Politeknik Negeri Kupang yang dengan giat dan berusaha untuk mengembangkan Dosen dalam membuat suatu karya ilmiah dalam bentuk penelitian yang lebih maju dari tahun-tahun sebelumnya

\section{DAFTAR PUSTAKA}

Asdak, Chay., (2010) Hidrologi dan Pengelolaan Daerah Aliran Sungai. Universitas Gajah Mada, Yogyakarta .

Direktorat Jenderal Sumber Daya Air (2013) Direktorat Irigasi dan Rawa,. Standart Perencanaan Irigasi : Kriteria Perencanaan Jaringan Irigasi (KP 01). Kementrian Pekerjaan Umum, Jakarta, 2013.

Mock, F.J, Dr, (1973) Land Capability Appraisal Indonesia, Water Availability Appraisal, UNDP/FAO, Bogor

Made Kamiana, (2011). Teknik Perhitungan Debit Rencana Bangunan Air, Penerbit Graha Ilmu, Yogyakarta,

Soemarto, B.I.E, Dipl. H, (1987). Hidrologi Teknik. Penerbit : Usaha Nasional, Surabaya 